\title{
Pengaruh sudut alur sekat terhadap unjuk kerja menara pendingin (cooling tower)
}

\section{A. Ardani, I. Qiram, G. Rubiono*}

Teknik Mesin, Fakultas Teknik, Universitas PGRI Banyuwangi, Jl. Ikan Tongkol 22 Banyuwangi Jawa Timur 68416, Indonesia, Telp. (0333) 421593, 423639

*Email: g.rubionov@gmail.com

\section{ARTICLE INFO}

Article History:

Received 15 September 2017

Accepted 10 October 2017

Available online 1 January 2018

Keywords:

Cooling tower

Buffle plot angle

Range

Performance

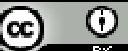

\begin{abstract}
Cooling tower is an equipment that use to decrease water temperature by extracting heat and emitting it to atmosphere. Cooling tower buffle is an important component that effect water flow. This research is aimed to get the effect of cooling tower buffle due to its performance which are range, heat transfer rate and efficiency. The research is done by experiment. Cooling tower buffle are varied in plot angle which are $5^{\circ}, 10^{\circ}, 15^{\circ}$ dan $20^{\circ}$. Water volume flow rate are varied as $50,75,100$ and $125 \mathrm{ml} / \mathrm{s}$. Inlet water tempersatur are varied as $50^{\circ}, 60^{\circ}$ and $70^{\circ} \mathrm{C}$. The measurements are done for water and air temperature at inlet and outlet points. The result shows that buffle plot angle has effect due to cooling tower performance.
\end{abstract}

\section{PENDAHULUAN}

Menara pendingin (cooling tower) digunakan sebagai alat pendingin fluida, dengan udara sebagai media pendingin (Taufik et al., 2014). Menara pendingin merupakan peralatan yang digunakan untuk menurunkan suhu aliran air dengan cara mengekstraksi panas dari air dan mengemisikan panas ke atmosfer (Pratiwi dkk., 2014). Menara pendingin juga dapat didefinisikan sebagai alat penukar kalor yang fluida kerjanya adalah air dan udara yang berfungsi mendinginkan air dengan kontak langsung dengan udara yang mengakibatkan sebagian kecil air menguap.

Air sebagai fluida yang digunakan dalam proses pendinginan umumnya masih dalam kondisi relatif panas. Pembuangan secara langsung ke lingkungan akan berpotensi menimbulkan bahaya bagi ekosistem lingkungan dan menyebabkan polusi thermal. Proses pendinginan secara alami di lingkungan atmosfer akan memerlukan waktu yang relatif lama dan tempat yang luas. Untuk itu, diperlukan proses pendinginan yang optimal yang salah satunya dapat dilakukan dengan mekanisme kerja menara pendingin.

Menara pendingin telah banyak digunakan terutama di industri yang memanfaatkan air sebagai alat/media pendingin untuk banyak peralatan yang memerlukannya. Beberapa menara-menara pendingin kuno berbentuk menara kosong tanpa bahan isian. Butiranbutiran air dijatuhkan dari puncak menara pendingin, sedangkan udara dihembuskan dari bawah. Dengan konfigurasi seperti ini maka akan terjadi kontak yang baik antara air panas dengan udara sebagai media pendingin (Johanes, 2011a).

Menara pendingin menggunakan prinsip penguapan dimana sebagian air diuapkan ke aliran udara yang bergerak dan kemudian dibuang ke atmosfir (Effendi dan Wirza, 2013). 
Untuk itu kinerja desain menara pendingin sangat dipengaruhi oleh temperatur lingkungan sekitar (Pratiwi et al., 2014). Agar perpindahan kalor lebih baik maka diperlukan media pengisi dengan konfigurasi sedemikian sehingga terjadi kontak yang baik antara air panas dengan udara sebagai media pendingin. Mekanisme perpindahan kalor utamanya adalah kalor sensibel dan kalor laten penguapan, kerugian kalor radiasi diabaikan serta prosesnya dianggap adiabatis. Dua faktor yang sangat menentukan laju perpindahan kalor dari air panas ke udara pendingin adalah waktu kontak dan luas permukaan antar fase (air dan udara). Dengan memberikan bahan isian pada menara, maka kedua faktor tersebut dapat diperbesar (Johanes, 2011b).

Penelitian menara pendingin telah banyak dilakukan untuk meningkatkan kinerjanya. Penelitian perbandingan unjuk kerja menara pendingin dilakukan untuk tipe induced counter flow (Wibisono, 2005), berdasarkan tipe susunan pipa-pipa sebagai pendistribusi cairan (Johanes, 2011b) dan jenis sirip horisontal dan vertikal (Patel and Mohite, 2015). Penelitian dilakukan untuk bahan isian ijuk (Johanes, 2010), tali ijuk (Johanes, 2011a) dan bambu wulung (Taufik et al., 2014). Perancangan menara pendingin dilakukan untuk menara pendingin skala laboratorium (Yulianto, Urbiantoro) dan aplikasi sistem kontrol (Effendi dan Wirza, 2013). Penelitian juga dilakukan untuk unjuk kerja menara pendingin (Fuhaid, 2008; Qian et al., 2012; Mayur, 2014; Pratiwi et al., 2014; Yadav and Soni, 2015).

Susunan atau konfigurasi sekat menara pendingin juga dapat meningkatkan unjuk kerja. Yulianto dan Urbiantoro merancang menara pendingin skala laboratorium dengan mengacu pada tipe shell dan tube untuk membandingkan luas bidang kontak air dan udara. Fuhaid (2008) meneliti pengaruh sudut kemiringan sekat terhadap unjuk kerja menara pendingin air. Johanes (2011b) meneliti komparasi karakteristik menara pendingin menggunakan beberapa tipe susunan pipa-pipa sebagai pendistribusi cairan. Patel and Mohite (2015) meneliti tipe sekat horisontal dan vertikal.

Penelitian perbandingan unjuk kerja menara pendingin telah dilakukan untuk tipe induced counter flow (Wibisono, 2005). Hasil penelitian menunjukkan bahwa rancangan yang menggunakan rak-rak penyusunan packing yang bertujuan untuk memudahkan sirkulasi udara, sehingga kontak air dan udara dapat berlangsung dengan maksimal dan menghasilkan kisaran serta kinerja pendinginan lebih besar. Kisaran terbesar dihasilkan pada pengukuran dengan beban pemanasan yang serupa dengan kondisi sebenarnya.

Penelitian berdasarkan tipe susunan pipapipa sebagai pendistribusi cairan dilakukan oleh Johanes (2011b). Hasil penelitian menunjukkan bahwa karakteristik menara pendingin mengalami kenaikan dengan bertambahnya tinggi pendistribusian cairan. Untuk nilai rasio laju aliran massa air terhadap udara yang rendah, karakteristik menara pendingin mengalami penurunan dengan bertambahnya jumlah sekat, sedangkan untuk rasio laju airan massa air terhadap udara yang tinggi, demikian pula sebaliknya. Penelitian jenis sirip horisontal dan vertikal dilakukan oleh Patel and Mohite (2015). Hasil penelitian menunjukkan bahwa unjuk kerja maksimum terjadi pada susunan sirip vertikal.

Penelitian dilakukan untuk bahan isian ijuk dilakukan oleh Johanes (2010). Hasil penelitian menunjukkan bahwa Karakteristik menara (NTU) mengalami kenaikan dengan bertambahnya tinggi bahan isian (Z). Untuk bahan tali ijuk (Johanes, 2011a), naiknya temperatur air masuk menara dan tinggi pak ijuk mengakibatkan naiknya nilai karakteristik menara pendingin. Untuk bahan bambu wulung (Taufik et al., 2014), Variasi penambahan bahan pengisi bambu wulung dan ketinggian dapat mempercepat pendinginan suhu awal.

Penelitian unjuk kerja menara pendingin oleh Fuhaid (2008) menunjukkan bahwa sudut kemiringan sekat berpengaruh terhadap pendinginan air. Semakin besar sudut sekat maka beda suhu juga semakin besar. Qian et al. (2012) menyatakan bahwa diperlukan desain dan aplikasi yang tepat untuk meningkatkan unjuk kerja menara pendingin sistem tertutup. Mayur (2014) mendapatkan bahwa area penyemprotan dan aliran air sangat berpengaruh terhadap unjuk kerja menara pendingin.

Pada menara pendingin, proses perpindahan kalor berlangsung dari air panas ke udara tak jenuh. Kontak langsung antara air panas dan udara akan menyebabkan terjadinya penguapan sebagian air tersebut. Ini merupakan kombinasi perpindahan kalor dan massa, sehingga perpindahan kalor yang terjadi adalah kalor sensibel dan kalor laten. Ada dua hal yang menyebabkan terjadinya perpindahan kalor yaitu perbedaan temperatur bola kering dan perbedaan tekanan parsiil antara permukaan air dan udara. Kedua penyebab ini berkombinasi membentuk potensial entalpi. Proses laju perpindahan kalor sensibel dari permukaan air panas ke udara merupakan proses perpindahan kalor konveksi, sehingga variabel yang menentukan adalah koefisien konveksi, luas bidang kontak (permukaan basah) dan beda temperatur air dan udara (Johanes, 2011a). 
Sekat-sekat menara pendingin merupakan salah satu faktor yang menentukan proses pendinginan dan kinerja menara pendingin. Dengan mengacu pada beberapa penelitian terdahulu yang mengkaji komponen sekat ini maka dapat dilakukan modifikasi sekat menara pendingin untuk meningkatkan unjuk kerja menara pendingin. Alur sekat akan mempengaruhi luas bidang kontak dan aliran tetes air. Hal ini akan mempengaruhi kontak air dengan udara pendingin sehingga akan berpengaruh terhadap proses pendinginan air.

\section{TINJAUAN PUSTAKA \\ Menara Pendingin}

Air dingin diperlukan untuk penyejuk udara/ AC, proses-proses manufakturing atau pembangkitan daya. Menara pendingin merupakan suatu peralatan yang digunakan untuk menurunkan suhu aliran air dengan cara mengekstraksi panas air dan mengemisikannya ke atmosfir. Menara pendingin menggunakan penguapan dimana sebagian air diuapkan ke aliran udara yang bergerak dan kemudian dibuang ke atmosfir. Terdapat 2 jenis utama menara pendingin: menara pendingin yaitu natural draft dan mechanical draft.

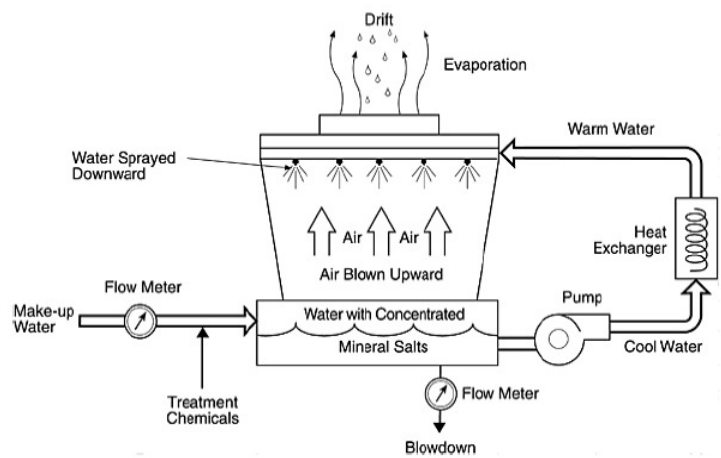

Gambar 1. Skema menara pendingin (UNEP)

- Menara pendingin jenis natural draft

Menara pendingin jenis natural draft atau hiperbola menggunakan perbedaan suhu antara udara ambien dan udara yang lebih panas di bagian dalam menara. Begitu udara panas mengalir ke atas melalui menara (sebab udara panas akan naik), udara segar yang dingin disalurkan ke menara melalui saluran udara masuk di bagian bawah. Tidak diperlukan fan dan hampir tidak ada sirkulasi udara panas yang dapat mempengaruhi kinerja.

- Menara Pendingin Draft Mekanik

Menara draft mekanik memiliki fan yang besar untuk mendorong atau mengalirkan udara melalui air yang disirkulasi. Air jatuh turun di atas permukaan bahan pengisi, yang membantu untuk meningkatkan waktu kontak antara air dan udara. Hal ini membantu dalam memaksimalkan perpindahan panas antara air dan udara. Laju pendinginan menara draft mekanis tergantung pada banyak parameter seperti diameter fan dan kecepatan operasi, bahan pengisi untuk tahanan sistim dan lainlain.

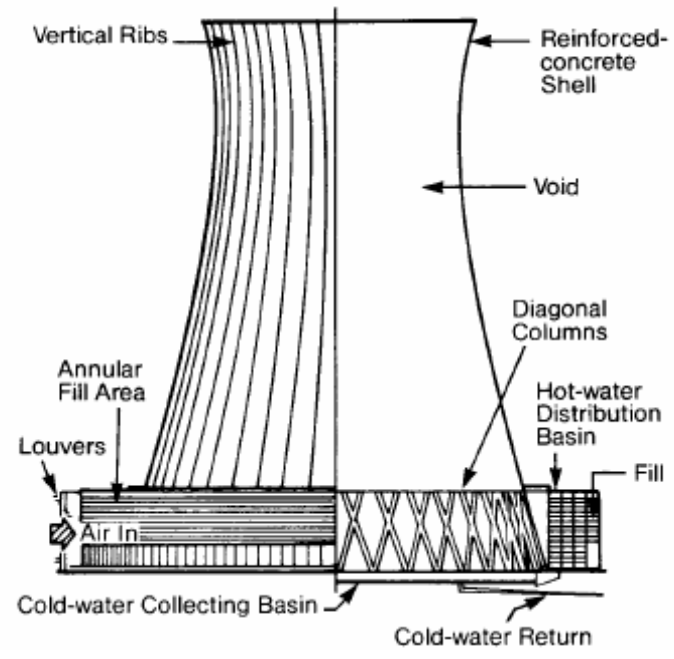

Gambar 2. Skema jenis natural draft (UNEP)

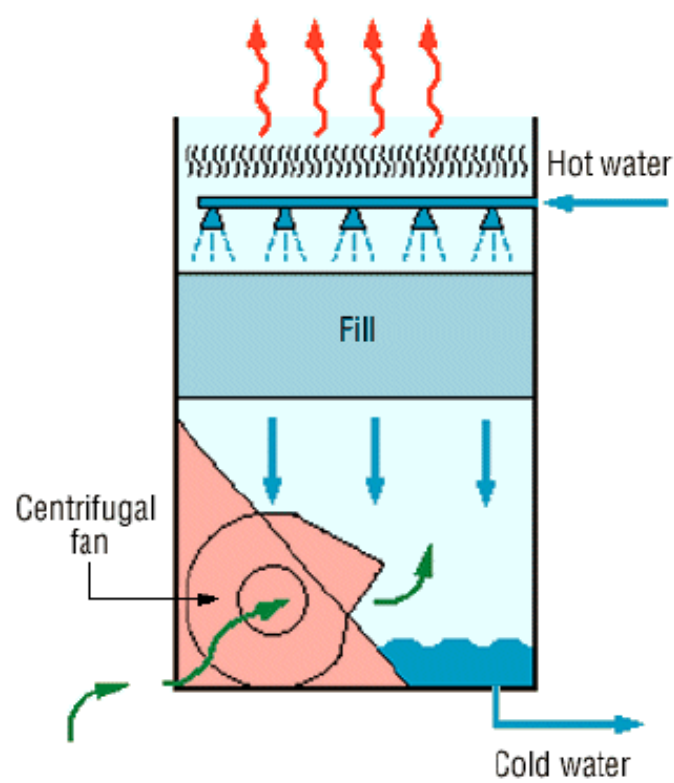

Gambar 3. Skema jenis draft mekanik (UNEP)

\section{Kinerja Menara Pendingin}

Kinerja menara pendingin digunakan untuk mengkaji tingkat approach dan range terhadap nilai desain, mengidentifikasi area terjadinya pemborosan energi dan memberikan saran perbaikan. Selama evaluasi kinerja cooling tower, peralatan pemantauan yang portable digunakan 
untuk mengukur evaluasi kinerja cooling tower. Pemantauan dilaksanakan untuk mengukur parameter-parameter signifikan berikut ini (Taufik et al., 2014):

1. Temperatur udara wet bulb

2. Temperatur udara dry bulb

3. Temperatur air masuk menara pendingin

4. Temperatur air keluar menara pendingin

5. Temperatur udara keluar

6. Laju aliran air

7. Laju aliran udara.

Parameter terukur tersebut kemudian digunakan untuk menentukan kinerja menara pendingin dengan beberapa cara yaitu:

1. Range merupakan perbedaan antara suhu air masuk dan keluar menara pendingin. Range CT (cooling tower) dirumuskan sebagai:

Range CT $\left({ }^{\circ} \mathrm{C}\right)=\left[\right.$ suhu masuk CW $\left({ }^{\circ} \mathrm{C}\right)-$ suhu keluar $\left.\mathrm{CW}\left({ }^{\circ} \mathrm{C}\right)\right]$.

2. Approach merupakan perbedaan antara suhu air dingin keluar menara pendingin dan suhu wet bulb ambien.

Approach $\mathrm{CT}\left({ }^{\circ} \mathrm{C}\right)=\left[\right.$ suhu keluar $\mathrm{CW}\left({ }^{\circ} \mathrm{C}\right)$ - suhu wet bulb $\left.\left({ }^{\circ} \mathrm{C}\right)\right]$.

3. Efektivitas. Merupakan perbandingan antara range dan range ideal (dalam persentase), yaitu perbedaan antara suhu masuk air pendingin dan suhu wet bulb ambien.

Efektivitas CT (\%) $=100 \times$ (suhu CW suhu keluar CW) / (suhu masuk CW suhu WB).

4. Kapasitas pendinginan. Merupakan panas yang dibuang satuan waktu sebagai hasil dari kecepatan aliran massa air, panas spesifik dan perbedaan suhu.

$q=\dot{m} \cdot C p \cdot \Delta T$

Dimana:

$\dot{m}=$ laju aliran massa $(\mathrm{kg} / \mathrm{dt})$

$\mathrm{Cp}=$ panas spesifik $(\mathrm{J} / \mathrm{kg} \mathrm{K})$

$\Delta T=$ beda suhu $(\mathrm{K})$

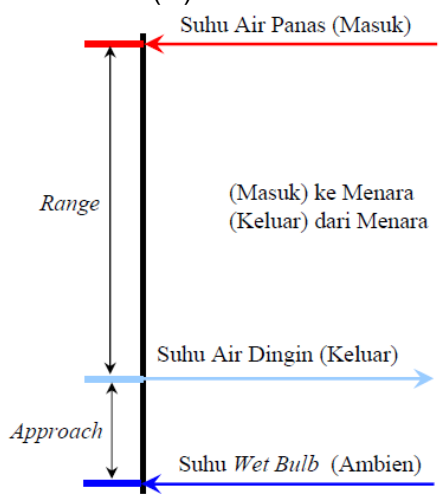

Gambar 4. Range dan approach (UNEP)

\section{METODOLOGI}

Variabel bebas meliputi alur sekat yang divariasikan dengan sudut $5^{\circ}, 10^{\circ}, 15^{\circ}$ dan $20^{\circ}$ (skema gambar 3 ). Debit aliran air sebesar 50 , 75, 100 dan $125 \mathrm{ml} / \mathrm{dt}$ dengan pengaturan katup pada pipa air. Suhu air masuk divariasikan sebesar $50^{\circ}, 60^{\circ}$ dan $70^{\circ} \mathrm{C}$ dengan menggunakan pemanas listrik. Variabel terikat meliputi suhu air masuk dan keluar, suhu udara masuk dan keluar. Pengukuran debit dilakukan dengan flowmeter dan stopwatch. Pengukuran suhu dilakukan dengan termokopel tipe $\mathrm{K}$. Peralatan menara pendingin yang digunakan adalah peralatan skala laboratorium berukuran penampang panjang $40 \mathrm{~cm}$, lebar $20 \mathrm{~cm}$ dan tinggi $70 \mathrm{~cm}$ seperti skema pada gambar 4 dan foto alat pada gambar 5 .

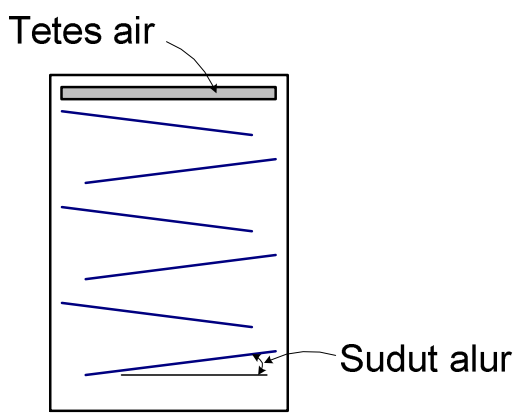

Gambar 3. Skema alur sekat (tampak atas)

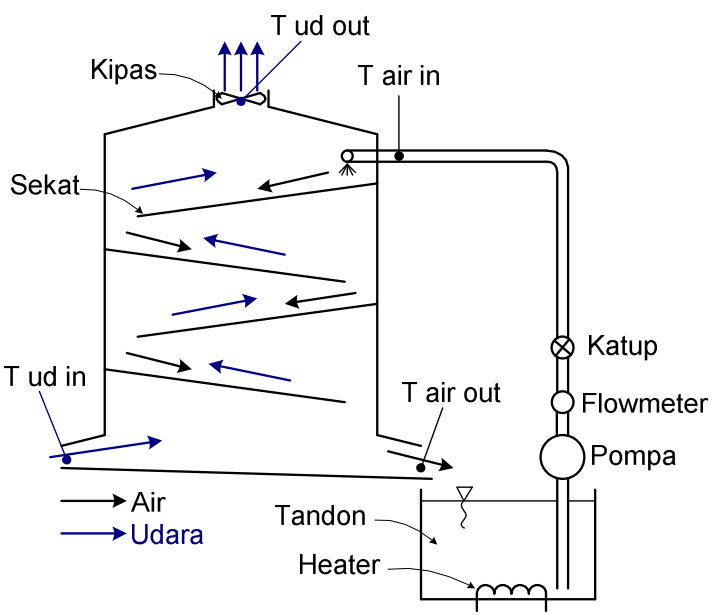

Gambar 4. Skema menara pendingin

Pengambilan data dilakukan dengan tahapan sebagai berikut:

1. Persiapan alat dan bahan. Sekat dipasang dengan sudut alur $5^{\circ}$

2. Pemanas air dan kipas dihidupkan. 
3. Pompa dihidupkan, katup dibuka untuk pengaturan debit $50 \mathrm{ml} /$ det.

4. Pengukuran-pengukuran suhu setiap menit selama 5 menit. Hasil pengukuran digunakan untuk menghitung nilai rata-rata.

5. Mengulangi percobaan untuk variasi yang lain.

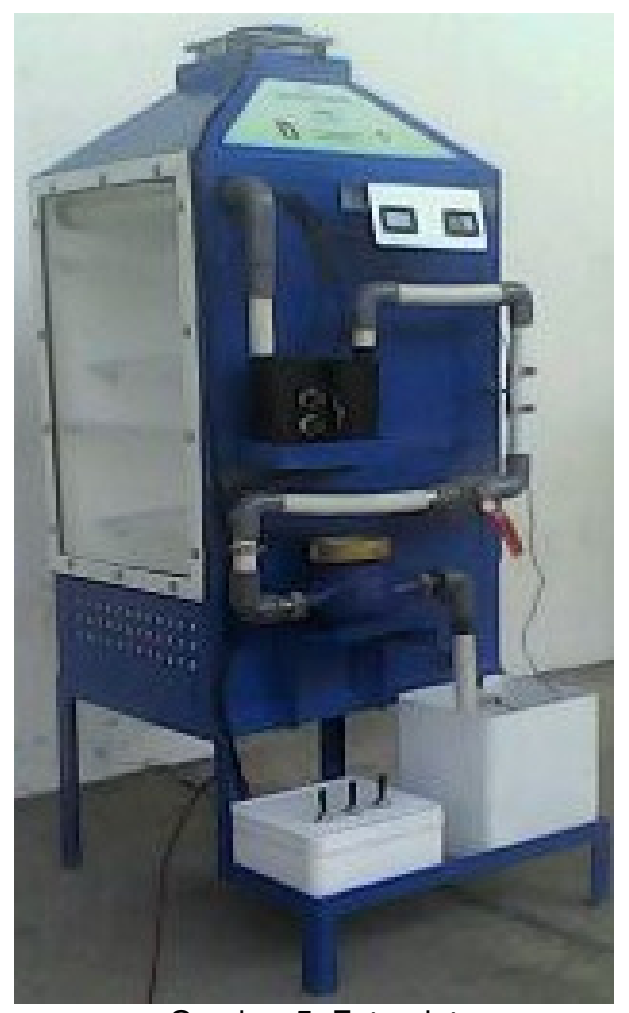

Gambar 5. Foto alat

\section{HASIL DAN PEMBAHASAN}

Tabel 1. Beda suhu air rata-rata (Range) $\left({ }^{\circ} \mathrm{C}\right)$

\begin{tabular}{cccccc}
\hline $\begin{array}{c}\text { Debit } \\
\text { (ml/dt) }\end{array}$ & \multirow{2}{*}{$\mathbf{T}_{\text {in }}\left({ }^{\circ} \mathbf{C}\right)$} & \multicolumn{4}{c}{ Sudut sekat } \\
\cline { 3 - 6 } & & $\mathbf{5}^{\mathbf{0}}$ & $\mathbf{1 0}^{\circ}$ & $\mathbf{1 5}^{\circ}$ & $\mathbf{2 0}^{\circ}$ \\
\hline \multirow{3}{*}{50} & 50 & 10.9 & 10.4 & 9.9 & 9.6 \\
& 60 & 18.2 & 17.4 & 16.7 & 15.0 \\
& 70 & 26.0 & 25.6 & 26.1 & 24.4 \\
75 & 50 & 10.4 & 9.8 & 9.5 & 8.7 \\
& 60 & 16.8 & 16.4 & 15.6 & 14.9 \\
& 70 & 25.2 & 25.9 & 23.8 & 23.2 \\
100 & 50 & 10.3 & 9.4 & 8.4 & 8.3 \\
& 60 & 16.3 & 15.2 & 15.9 & 14.5 \\
& 70 & 25.0 & 23.6 & 22.7 & 21.9 \\
& 50 & 9.6 & 8.0 & 7.3 & 7.0 \\
125 & 60 & 15.3 & 14.9 & 15.2 & 13.7 \\
& 70 & 29.0 & 28.2 & 27.7 & 27.9 \\
\hline
\end{tabular}

Tabel 2. Beda suhu udara rata-rata $\left({ }^{\circ} \mathrm{C}\right)$

\begin{tabular}{cccccc}
\hline $\begin{array}{c}\text { Debit } \\
\text { (ml/dt) }\end{array}$ & \multirow{2}{*}{$\mathbf{T}_{\text {in }}\left({ }^{\circ} \mathbf{C}\right)$} & \multicolumn{4}{c}{ Sudut sekat } \\
\cline { 2 - 5 } $\mathbf{5}^{\circ}$ & $\mathbf{1 0}^{\circ}$ & $\mathbf{1 5}^{\circ}$ & $\mathbf{2 0}^{\circ}$ \\
\hline \multirow{3}{*}{50} & 50 & 8.1 & 7.9 & 7.3 & 7.8 \\
& 60 & 7.1 & 7.5 & 6.9 & 6.8 \\
& 70 & 5.5 & 5.3 & 5.1 & 4.9 \\
75 & 50 & 7.7 & 7.6 & 7.4 & 7.0 \\
& 60 & 7.1 & 7.2 & 6.6 & 6.4 \\
& 70 & 4.9 & 4.7 & 4.8 & 4.6 \\
100 & 50 & 7.3 & 7.4 & 6.8 & 7.3 \\
& 60 & 5.0 & 5.3 & 4.6 & 5.0 \\
& 70 & 4.3 & 3.9 & 3.8 & 4.7 \\
125 & 50 & 6.9 & 6.4 & 6.5 & 6.2 \\
& 60 & 4.4 & 4.3 & 4.1 & 4.0 \\
& 70 & 4.1 & 3.5 & 3.9 & 2.8 \\
\hline
\end{tabular}

Tabel 3. Kapasitas Panas (W/dt)

\begin{tabular}{cccccc}
\hline Debit & $\begin{array}{c}\mathbf{T}_{\text {in }} \\
\text { (ml/dt) }\end{array}$ & \multicolumn{4}{c}{ Sudut sekat } \\
\cline { 3 - 6 } & $\left.{ }^{\circ} \mathbf{C}\right)$ & $\mathbf{5}^{\circ}$ & $\mathbf{1 0}^{\circ}$ & $\mathbf{1 5}^{\circ}$ & $\mathbf{2 0}^{\circ}$ \\
\hline \multirow{4}{*}{50} & 50 & 58.29 & 55.91 & 52.94 & 51.06 \\
& 60 & 62.98 & 60.63 & 58.39 & 52.45 \\
& 70 & 67.36 & 66.15 & 67.97 & 63.38 \\
75 & 50 & 55.91 & 52.97 & 50.80 & 46.77 \\
& 60 & 58.33 & 57.14 & 54.55 & 52.10 \\
& 70 & 65.63 & 67.10 & 61.82 & 59.79 \\
& 50 & 55.08 & 50.54 & 45.65 & 44.62 \\
100 & 60 & 56.99 & 53.71 & 55.79 & 51.06 \\
& 70 & 64.43 & 61.14 & 58.81 & 56.59 \\
& 50 & 51.06 & 43.01 & 39.04 & 37.43 \\
125 & 60 & 54.06 & 51.92 & 53.15 & 47.90 \\
& 70 & 74.94 & 73.25 & 71.58 & 72.28 \\
\hline
\end{tabular}

Tabel 4. Efektifitas (\%)

\begin{tabular}{cccccc}
\hline Debit & $\mathbf{T}_{\text {in }}$ & \multicolumn{4}{c}{ Sudut sekat } \\
\cline { 3 - 6 } (ml/dt) & $\left.\mathbf{(}^{\circ} \mathbf{C}\right)$ & $\mathbf{5}^{\mathbf{0}}$ & $\mathbf{1 0}^{\circ}$ & $\mathbf{1 5}^{\circ}$ & $\mathbf{2 0}^{\circ}$ \\
\hline \multirow{3}{*}{50} & 50 & 58.29 & 55.91 & 52.94 & 51.06 \\
& 60 & 62.98 & 60.63 & 58.39 & 52.45 \\
& 70 & 67.36 & 66.15 & 67.97 & 63.38 \\
75 & 50 & 55.91 & 52.97 & 50.80 & 46.77 \\
& 60 & 58.33 & 57.14 & 54.55 & 52.10 \\
& 70 & 65.63 & 67.10 & 61.82 & 59.79 \\
& 50 & 55.08 & 50.54 & 45.65 & 44.62 \\
100 & 60 & 56.99 & 53.71 & 55.79 & 51.06 \\
& 70 & 64.43 & 61.14 & 58.81 & 56.59 \\
& 50 & 51.06 & 43.01 & 39.04 & 37.43 \\
125 & 60 & 54.06 & 51.92 & 53.15 & 47.90 \\
& 70 & 74.94 & 73.25 & 71.58 & 72.28 \\
\hline
\end{tabular}




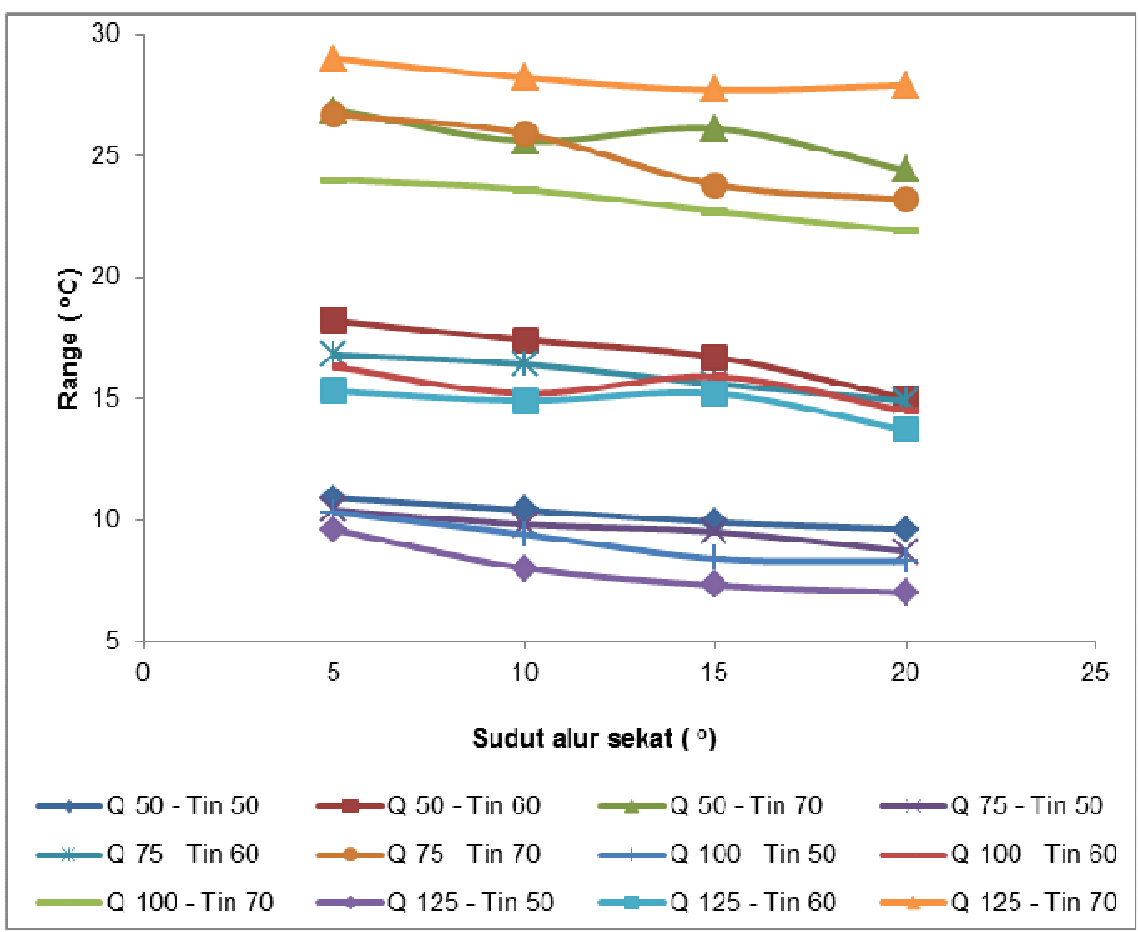

Gambar 6. Beda suhu air (range)

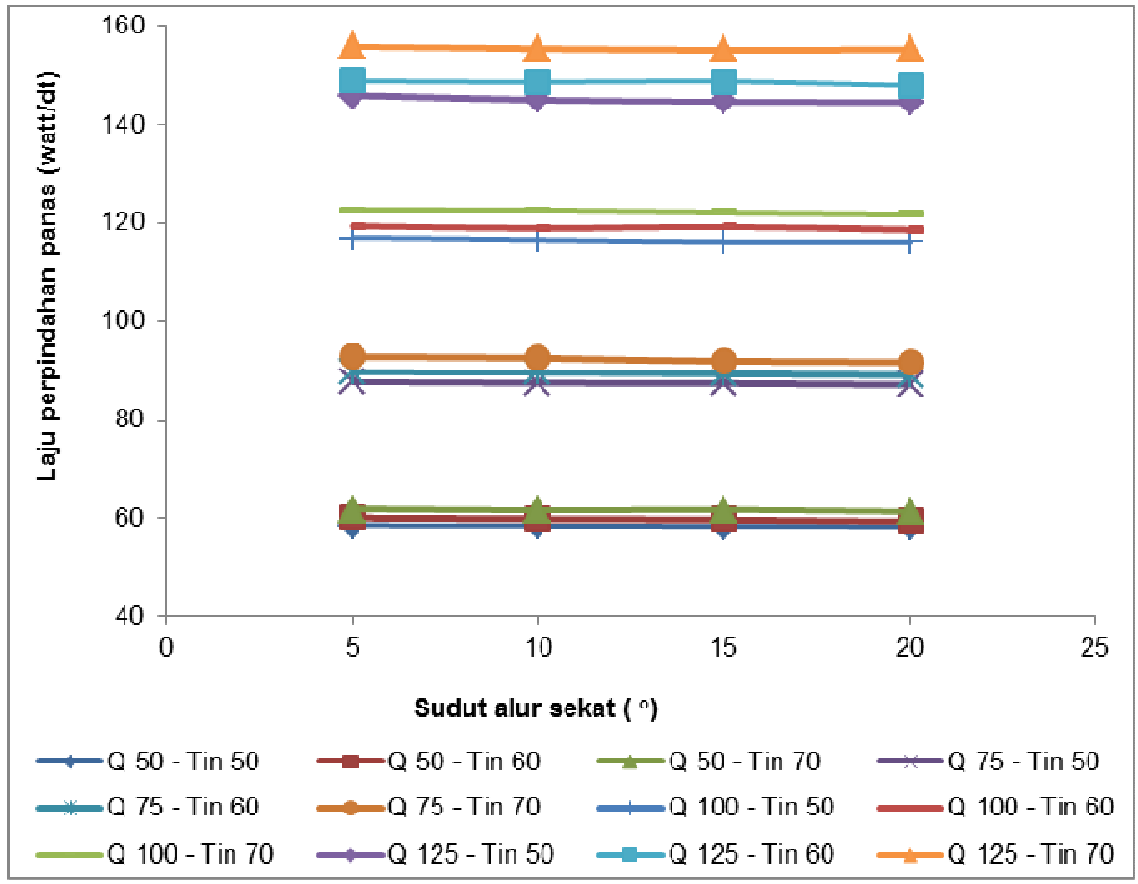

Gambar 7. Laju perpindahan panas 


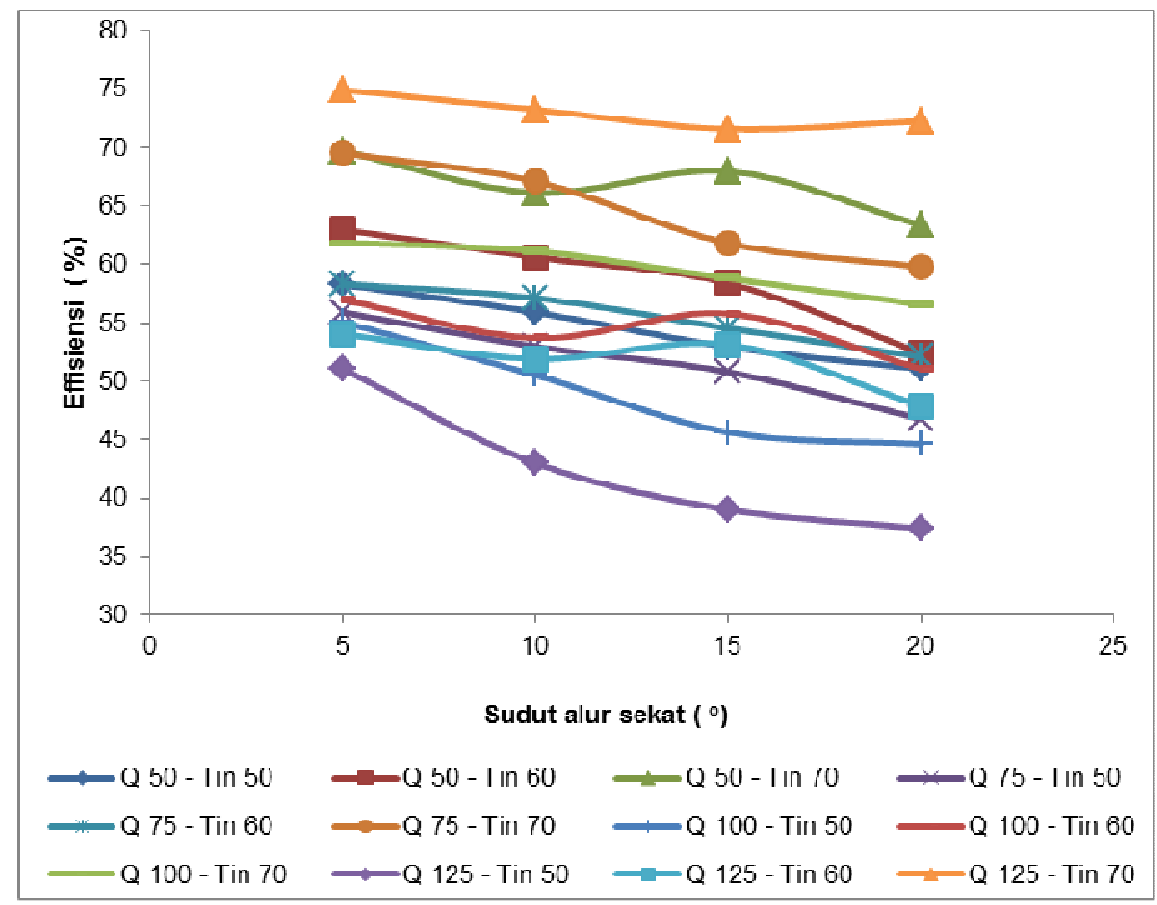

Gambar 8. Efisiensi

Data-data pada tabel 1 dan 2 selanjutnya digunakan untuk menghitung kapasitas pendinginan (laju perpindahan panas) dan efektifitas (efisiensi) menara pendingin. Berikut ini contoh perhitungan untuk data variasi debit 50 $\mathrm{ml} / \mathrm{dt}$, suhu air masuk $50^{\circ} \mathrm{C}$ dan sudut alur sekat $5^{\circ}$ dimana suhu air masuk rata-rata $50,2^{\circ} \mathrm{C}$ dan suhu air keluar rata-rata $39,3^{\circ} \mathrm{C}$.

a. Laju perpindahan panas: dapat dihitung dengan persamaan (1), dan laju aliran massa dapat dihitung dengan persamaan:

$\dot{m}=\rho Q$

Dengan $\rho$ adalah berat jenis $\left(\mathrm{kg} / \mathrm{m}^{3}\right), \quad Q$ menyatakan debit aliran $\left(\mathrm{m}^{3} / \mathrm{dt}\right)$, dan untuk densitas air $986 \mathrm{~kg} / \mathrm{m}^{3}$.

$\dot{m}=(986)(0,05)=49,3 \mathrm{~kg} / \mathrm{s}$

Nilai cp air sebesar $0,004185 \mathrm{~J} / \mathrm{kg} \mathrm{K}$ sehingga:

$q=49,3 \times 0,004185 \times 10,9$

$=58,29 \mathrm{~W} / \mathrm{dt}$

b. Efektivitas panas.

Efektivitas CT $(\%)=100 \times$ (suhu CW - suhu keluar CW) / (suhu masuk CW - suhu WB). Dengan suhu WB (suhu bola basah) sebesar $31,5^{\circ} \mathrm{C}$ maka:

Efektivitas $=(50,2-39,3) /(50,2-31,5)$

$=58,29 \%$. Dengan cara yang sama didapat hasilhasil perhitungan seperti pada table 3 .
Gambar 6 menunjukkan bahwa beda suhu cenderung berkurang jika sudut alur sekat semakin besar. Hal ini disebabkan pada sudut alur yang lebih kecil, air mendapatkan lintasan gerak yang lebih panjang. Lintasan gerak ini akan memberikan waktu yang lebih besar pada proses pendinginan dengan aliran udara. Beda suhu maksimum terjadi pada variasi sudut alur sekat $5^{\circ}$, temperatur air masuk $70^{\circ} \mathrm{C}$ dan debit aliran air $125 \mathrm{ml} / \mathrm{dt}$ yaitu sebesar $29,0^{\circ} \mathrm{C}$. Beda suhu minimum terjadi pada variasi sudut alur sekat $20^{\circ}$, temperatur air masuk $50^{\circ} \mathrm{C}$ dan debit aliran air $125 \mathrm{ml} / \mathrm{dt}$ yaitu sebesar $7,0^{\circ} \mathrm{C}$.

Grafik laju perindahan panas pada gambar 7 menunjukkan bahwa semakin besar sudut alur sekat maka laju perpindahan panas cenderung semakin kecil. Hal ini disebabkan karena beda suhu yang semakin kecil karena laju perpindahan panas tergantung pada beda suhu yang terjadi. Selain itu laju juga dipengaruhi debit aliran karena debit akan menentukan besarnya laju aliran massa. Temperatur air masuk juga menentukan nilai panas spesifik (cp) dimana semakin besar temperatur maka panas spesifik juga semakin besar. Laju perpindahan panas maksimum terjadi pada variasi sudut alur sekat $5^{\circ}$, temperatur air masuk $70^{\circ} \mathrm{C}$ dan debit aliran air $125 \mathrm{ml} / \mathrm{dt}$ yaitu sebesar 155,77 W/dt. Beda suhu minimum terjadi pada variasi sudut alur sekat 
$20^{\circ}$, temperatur air masuk $50^{\circ} \mathrm{C}$ dan debit aliran air $50 \mathrm{ml} / \mathrm{dt}$ yaitu sebesar 58,31 W/dt.

Gambar 8 menunjukkan bahwa semakin besar sudut alur sekat maka efisiensi cenderung menurun. Hal ini disebabkan karena beda suhu air yang terjadi dimana beda suhu cenderung berkurang jika sudut alur sekat semakin besar. Efisiensi maksimum terjadi pada variasi sudut alur sekat $5^{\circ}$, temperatur air masuk $70^{\circ} \mathrm{C}$ dan debit aliran air $125 \mathrm{ml} / \mathrm{dt}$ yaitu sebesar 74,94\%. Efisiensi minimum terjadi pada variasi sudut alur sekat $20^{\circ}$, temperatur air masuk $50^{\circ} \mathrm{C}$ dan debit aliran air $50 \mathrm{ml} / \mathrm{dt}$ yaitu sebesar $51,06 \%$.

Secara umum, fenomena yang terjadi adalah butiran-butiran air yang jatuh akan mengalir dalam bentuk lapisan tipis (thin layer) di atas permukaan sekat. Aliran ini selanjutnya akan tertahan oleh alur sekat pertama yang berfungsi penjadi penghalang aliran. Air yang mengalir sepanjang alur sekat dan selanjutnya akan tertahan di alur yang kedua dan seterusnya. Sudut alur sekat yang semakin besar akan menghasilkan sudut yang curam sehingga aliran air akan menjadi lebih cepat. Hal ini akan mengurangi waktu kontak dengan aliran udara pendingin sehingga proses pendinginan cenderung menjadi berkurang.

Grafik laju perpindahan panas pada gambar 7 menunjukkan bahwa semakin besar sudut alur sekat maka laju perpindahan panas cenderung semakin kecil. Di sisi lain, grafik efisiensi pada gambar 8 menunjukkan bahwa semakin besar sudut alur sekat maka efisiensi cenderung menurun. Hal ini menunjukkan kesesuaian fenomena yang terjadi alju perpindahan panas berbanding lurus terhadap efisiensi. Laju perpindahan panas yang kecil merupakan transfer energi dalam bentuk temperatur air dan aliran udara yang kecil pula. Besaran laju perpindahan panas ini akan mempengaruhi efisiensi karena salah satu indikator efisiensi adalah besaran energi yang dipindahkan dalam fenomena perpindahan panas ini.

\section{KESIMPULAN DAN SARAN}

Berdasarkan hasil dan pembahasan maka dapat diambil kesimpulan:

1. Sudut alur sekat berpengaruh terhadap unjuk kerja menara pendingin.

2. Semakin besar sudut alur sekat maka beda suhu cenderung berkurang.

3. Semakin besar sudut alur sekat maka laju perpindahan panas cenderung semakin kecil.

4. Semakin besar sudut alur sekat maka efisiensi cenderung menurun.

Untuk penelitian selanjutnya dapat dilakukan dengan melakukan modifikasi profil permukaan atau kekasaran sekat. Penelitian juga dapat dilakukan dengan merubah bentuk alur sekat lurus dalam penelitian ini menjadi bentuk alur yang lain.

\section{UCAPAN TERIMA KASIH}

Penelitian ini dilaksanakan dengan skim Program Kreativitas Mahasiswa-Penelitian (PKM-P) Kemenristek Dikti tahun anggaran 2017.

\section{DAFTAR PUSTAKA}

Effendi A., Wirza R., 2013, Perencanaan sistem scada cooling tower menggunakan siemens simatic step 7 dan wincc, Jurnal Teknoif, 1(1), 6-14.

Fuhaid N., 2008, Pengaruh sudut kemiringan sekat terhadap unjuk kerja menara pendingin air, Widya Teknika, 16(2), 45-53.

Johanes S., 2010, Karakteristik menara pendingin dengan bahan isian ijuk, Forum Teknik, 33(3), 188-194.

Johanes S., 2011a, karakteristik menara pendingin dengan bahan isian tali ijuk, Jurnal Teknologi Technoscientia, 4(1), 103-113.

Johanes S., 2011b, Komparasi karakteristik menara pendingin menggunakan beberapa tipe susunan pipa-pipa sebagai pendistribusi cairan, Forum Teknik, 34(1), 67-75.

Mayur A.R., 2014, Performance improvement of natural draft cooling tower, International Journal of Engineering Research and Reviews (IJERR), 2(1), 7-15.

Patel K., Mohite N.V., 2015, Experimental investigation of forced draft counter flow cooling tower with twisted tape insert: horizontal \& vertical, International Journal on Recent and Innovation Trends in Computing and Communication, 3(5), 2795-2798.

Pratiwi N.P., Nugroho G., Hamidah N.L., 2014, Analisa kinerja cooling tower induced draft tipe lbc w-300 terhadap pengaruh temperatur lingkungan, Jurnal Teknik Pomits, 7(7), 1-6.

Qian J., Li L., Tan Y., Zheng D., 2012, Research and application of closed cooling tower, $2^{\text {nd }}$ International Conference on Electronic \& Mechanical Engineering and Information Technology, 2213-2215.

Taufik H.A., Listyadi S.D., Sutjahjono H., 2014, Analisis beban kalor cooling tower induced draft counterflow dengan bahan pengisi bambu wulung, Artikel Ilmiah Hasil Penelitian Mahasiswa, Jurusan Teknik 
Mesin, Fakultas Teknik, Universitas Jember.

UNEP, 2017, Menara pendingin, pedoman efisiensi energi untuk industri di Asia, www.energy efficiencyasia.org.

Wibisono Y., 2005, Perbandingan unjuk kerja antar bahan pengisi pada menara pendingin tipe induced counter flow, Jurnal Teknologi Pertanian, 6(3), $152-162$.

Yadav B,K., Soni S.L., 2015, Experimental study of the performance of cooling tower, International Journal of Science and Research (IJSR), 4(8), 2035-2038. 